\title{
PENYULUHAN KESEHATAN DI MASA PANDEMI DAN NEW NORMAL MENGGUNAKAN MEDIA EDUKATIF BERBASIS AUDIO VISUAL
}

\author{
Vika Martahayu'1), Yuanita1) \\ 1)Program Studi Pendidikan Matematika, STKIP Muhammadiyah Bangka Belitung, Pangkal Pinang, Bangka Belitung, \\ Indonesia \\ Corresponding author : Vika Martahayu \\ E-mail : Vika.martahayu@stkipmbb.ac.id
}

Diterima 23 November 2020, Direvisi 19 Desember 2020, Disetujui 19 Desember 2020

\begin{abstract}
ABSTRAK
Pelaksanaan Pengabdian Mayarakat ini bertujuan untuk memberikan edukasi khususnya bagi anakanak melalui penyuluhan kesehatan di masa pandemi dan new normal menggunakan media edukatif berbasis audio visual. Pengabdian penyuluhan kesehatan dimasa pandemi menjadi salah satu alternatif dalam memberikan edukasi pada pengenalan kesehatan. Kegiatan ini dimulai dengan pengembangan media terlebih dahulu yang menyesuaikan dengan kebutuhan anak-anak baik dari segi gambar, warna, bahasa dan suara yang digunakan. Peserta dalam penyuluhan kesehatan ini terdiri dari sekolah terdekat SD STKIP Muhammadiyah Bangka Belitung diberikan secara offline sedangkan online via zoom dari SD N 4 Tempilang, SD N 13 Tempilang dan SD IT Alam Cahaya Tobolai yang dilaksanakan pada tanggal 17 September 2020 secara bersamaan dengan total 72 peserta terdiri dari siswa dan guru. Setelah diberikan penyuluhan dapat memberikan edukasi untuk menanamkan pehamanan yang kuat dalam menghadapi new normal. Perlunya pemberian edukasi melalui media berbasis audio visual bisa dirasakan bahwasanya covid-19 ini bukanlah sesuatu yang menakutkan sehingga menimbulkan rasa cemas yang berlebihan, tinggal bagaimana kita menyikapinya dengan baik dan mampu menjalankan sesuatunya berdasarkan protokol kesehatan.
\end{abstract}

Kata kunci : kesehatan; masa pandemi dan new normal; media edukatif berbasis audio visual.

\begin{abstract}
The implementation of this Community Service aims to provide education, especially for children, through health education during the pandemic and new normal using audio-visual based educational methods. Community health education services during the pandemic period is an alternative in providing education on the introduction of health. This activity begins with the development of media in advance that adapts to the needs of the children both in terms of images, colors, language and sounds used. Participants in this health education consisted of the closest school SD STKIP Muhammadiyah Bangka Belitung given offline while online via zoom from SD N 4 Tempilang, SD N 13 Tempilang and SD IT Alam Cahaya Tobolai which was held on September 17, 2020 simultaneously with a total of 72 participants consisted of students and teachers. After being given counseling, it can provide education to instill a strong understanding in facing thenew normal. The need to provide education through audiovisual based media can be felt that Covid-19 is not something scary that causes excessive anxiety, it's just how we react to it and are able to carry out things based on health protocols.
\end{abstract}

Keywords: health; pandemic period and new normal; audio-visual based educational media.

\section{PENDAHULUAN}

Tahun 2020 mungkin tidak akan pernah terlupakan oleh semua orang, cobaan hidup dimana-mana dari bencana alam, perekonomian menurun, masalah sosial, dan kesehatan. Awal tahun di Indonesia dilanda demam berdarah dengue (DBD)

Virus corona seolah menjadi momok menakutkan yang dialami seluruh dunia, bagaimana tidak, semua aktivitas dihentikan dari pendidikan, perindustrian, instansi-instansi lainnya semua dianjurkan untuk melakukan kewajibannya dirumah, perekonomian setiap negara menurun, segala aspek kehidupan terpengaruh dengan dampak virus corona ini. Sudah hampir 3 bulan lebih pemerintah menerapkan kebijakan untuk segala aktifitas dan proses belajarpun dari rumah, ini semua tentu karena wabah virus corona atau Covid-19 yang kini penyebebarannya makin meluas ke seluruh daerah di Indonesia.

Pemerintah dan pihak terkait sudah melakukan upaya pencegahan dan penanganan dengan maksimal, dari menetapkan kebijakan-kebijakan, melakukan penyuluhan, turun tangan langsung, 
sebenarnya dalam permasalahan ini bukan hanya pemerintah saja yang harus menjadi agen penyelesai permasalahan, tetapi semua orang berkewajiban melakukannya, siapapun itu.

Angka pasien sembuh dari virus Corona di Provinsi Kepulauan Bangka Belitung (Babel) terus meningkat dibandingkan dengan jumlah pasien yang dirawat. Per hari ini, tingkat kesembuhan pasien Corona mencapai 80 persen"Tingkat kesembuhan pasien dari virus Corona di Babel mencapai 80 persen, setelah ada penambahan 10 hari ini," kata Sekretaris Gugus Tugas COVID-19 Babel, Mikron Antariksa, kepada detikcom, Selasa (23/6/2020). Untuk diketahui, jumlah kasus positif di Babel dalam tiga hari yang berbeda tidak ada tambahan sehingga, dari 148 kasus terkonfirmasi COVID-19 di Babel, 117 orang sudah dinyatakan sembuh. Sedangkan yang meninggal dunia 2 orang dan 29 orang masih dalam perawatan di Wisma Karantina Bangka Belitung.

"Untuk tingginya kasus yang sembuh ini merupakan doa kita semua dan juga kinerja tim kesehatan terutama yang bertugas di wismawisma karantina di Babel. Semoga ini menjadi kabar baik untuk kita semua,".

Informasi terkait Covid-19 yang di dapatkan masyarakat umumnya baik dari media masa, stasiun TV yang di telan mentahmentah tanpa mencari tahu kebenaranannya seperti apa. Terutama masyarakat yang tinggal di pelosok yang secara perkembangan zaman masih banyak sekali yang tidak memamahi dengan benar apa itu covid-19. Info yang mereka dapatkan terkadang hanya dari mulut kemulut dan akhirnya rasa ketakutan begitu kuat dengan adanya Covid-19.

Menghadapi new normal ini, kurang pemahaman masyarakat khususnya anak-anak tentang Covid-19 ini menjadi sesuatu yang biasa saja, padahal dampak dari Covid-19 ini mampu membuat banyak orang merasakan rasa cemas yang berlebihan sehingga merasa stres. Dengan hal tersebut perlunya pemberian penanaman secara mendalam selama covid-19 ini melalui "Penyuluhan Kesahatan di Masa Pandemi Menggunakan Media Edukatif Berbasis Audio visual".

Dari beberapa paparan diatas untuk menanamkan pehamanan yang kuat dalam menghadapi new normal perlunya pemberian edukasi melalui media berbasis audio visual. Dengan audio visual ini bisa dirasakan khususnya masyarakat umum bahwasanya covid-19 ini bukanlah sesuatu yang menakutkan sehingga menimbulkan rasa cemas yang berlebihan, tinggal bagaimana kita menyikapinya dengan baik dan mampu menjalankan sesuatunya berdasarkan protokol kesehatan.

Dengan memperhatikan hal tersebut, sangat perlu adanya kolaborasi dari semua pihak untuk melakukan tindakan preventif atas kondisi saaat ini yang dimana penting pemahaman dan pengetahuam terhadapan pandemi covid-19. Akan tetapi pemahaman dan pengetahuan tidaklah cukup tanpa adanya perubahan pada diri sendiri. Perubahan diri sendiri perlu adanya manajemen yang dikenal dengan manajemen diri sehingga akan ada kolaborasi melalui penyuluhan kesehatan di perkuat dalam implementasinya dengan manajemen diri.

Menurut Muliyadi; M. Yasdar; Fitriani Sulaeman (2017), Manajemen diri adalah suatu proses yang dilakukan oleh individu dalam mengarahkan perilakunya dengan menggunakan suatu siasat atau kombinasi siasat terapi agar mampu berpeirlaku positif dan produktif. Manajemen diri itu merupakan salah satu cara yang lazim digunakan dalam tradisi bimbingan dan konseling. Penggunaannya dapat dikenakan kepada berbagai sasaran perilaku. Manajemen diri merupakan salah satu bentuk latihan yang mudah sekaligus murah. Penerapan manajemen diri yang baik pada kehidupan akan membuat seseorang dapat menikmati proses hidup dan mampu mencapai tujuan yang diharapkan. Salah satu manfaat dari manajemen diri sendiri adalah melepaskan stress, kecemasan, kemarahan, ketakutan dan dendam dan sakit hati, Memecahkan dan menyelesaikan berbagai permasalahan, meningkatkan citra dan rasa percaya diri.

Penyuluhan kesehatan adalah kegiatan pendidikan kesehatan, yang dilakukan dengan menyebarkan pesan, menanamkan keyakinan, sehingga masyarakat tidak saja sadar, tahu dan mengerti, tetapi juga mau dan bisa melakukan suatu anjuran yang ada hubungannya dengan kesehatan dengan tujuan tercapainya perubahan perilaku individu, keluarga dan masyarakat dalam membina dan memelihara perilaku sehat dan lingkungan sehat, serta berperan aktif dalam upaya mewujudkan derajat kesehatan yang optimal, (Haryani., Sahar., Sukihananto, 2017). Penyuluhan di sini di sampaikan dengan media audio visual, dengan audio visual ini mampu memberikan edukasi yang khususnya pada anak-anak dan umumnya bagi masyarakat.

Media audio visual adalah media yang mempunyai unsur suara gambar. Jenis media ini mempunyai kemampuan yang lebih baik, karena meliputi kedua jenis media yaitu Media Audio dan Media Visual. Media berbasis audio visual mengandung penggunaan suara 
tambahan untuk memproduksinya. Jadi dapat disimpulkan bahwa Media audio visual adalah seperangkat alat yang dapat memproyeksikan gambar bergerak dan bersuara. Paduan antara gambar dan suara membentuk karakter sama dengan obyek aslinya. Penggunaan media audio visual dapat mempertinggi perhatian anak dengan tampilan yang menarik. Selain itu, anak akan takut ketinggalan jalannya video tersebut jika melewatkan dengan mengalihkan konsentrasi dan perhatian. Media audio visual yang menampilkan realitas materi dapat memberikan pengalaman nyata pada siswa saat mempelajarinya sehingga mendorong adanya aktivitas diri (Fujianto.,A. Jayadinata.,K.,A. Kurnia.,D. 2016).

Media ini tepat dan banyak manfaatnya diantaranya adalah: karena dapat menarik perhatian khususnya bagi anak-anak, mengandung pesan-pesan moral kesehatan dalam covid-19 dan mampu melihat, merasakan, dan memilika gambaran yang nyata bukan dalam imajinasi saja dengan apa yang mereka dengarkan selama ini terkait covid-19.

\section{METODE}

Pengabdian Masyarakat ini dilaksanakan di Sekolah terdekat yaitu SD STKIP Muhammadiyah Bangka Belitung yang di lakukan secara offline dan SD Negeri 4 Tempilang, SD Negeri 13 Tempilang, SD IT Alam Cahaya Toboali dilaksanakan secara online via zoom.

Pelaksanaan ini dilaksanakan secara bersamaan dengan hari yang sama yaitu pada hari Kamis Tanggal 17 September 2020. Peserta Offline sekolah terdekat berjumlah 31 dari siswa dan 5 dari guru, sedangkan peserta online dari 3 sekolah berjumlah 36 peserta dari siswa dan 3 dari guru, jadi total peserta berjumlah 72 peserta.

\section{HASIL DAN PEMBAHASAN}

Pengabdian penyuluhan kesehatan dimasa pandemi menjadi salah satu alternative dalam memberikan edukasi pada pengenalan kesehatan. Pada pelaksanaanya pelaksana menggunakan media berbasis Audio visual yang menarik dan bisa didengar serta di tonton karena memiliki tampilan yang disesuaikan untuk semua kalangan. Beberapa tahapan pelaksanaan pengabdian masyarakat yang telah dilaksanakan antara lain:

1) Analisis kebutuhan dan masalah di lapangan untuk menyusun materi pada media yang akan digunakan. Analisis kebutuhan akan di berikan pertanyaan kepada bermacam subjek agar video yang dibuat bisa digunakan dan diberikan kesemua orang. Materi yang disampaikan pada kegiatan penyuluhan sebagai berikut:

a. Edukasi Mengenal Pentingnya menjaga kesehatan

b. Edukasi Mengenal berbagai macam Penyakit

c. Edukasi manajemen diri pada kesehatan

d. Edukasi dari pakar kesehatan di masa pendemi dan new normal

2) Penyusunan media edukatif berbasis audio visual.

Pada pembuatannya peneliti menggunakan media audio visual berbentuk video dengan desain dan materi berdasarkan hasil analisis kebutuhan. Pada pembuatannya pelaksana menggunakan program (Kinemaster) yang di dalam nya berisi:

a. Gambar. Gambar-gambar yang disajikan berupa kartun dan gambar real (konkrit) dan menarik sehingga tidak terkesan membuat cemas dan menakutkan ketika seseorang ingin mengenal lebih jauh mengenai edukasi kesehatan dimasa pendemi dan new normal

b. Materi-materi.

Media yang sudah di buatkan telah diperiksa oleh uji ahli sehingga sesuai dengan kajian dan kepakarannya. Diantaranya Ahli Psikologi, Ahli Bahasa/media, Ahli Kesehatan, dan Ahli pendidikan.

c. Suara. Suara diisi langsung oleh pelaksana dan dengan mengkombinasikan musik yang menarik sehingga penonton akan lebih tertarik.

d. Durasi. Durasi video akan berkisar antar 1015 menit ।

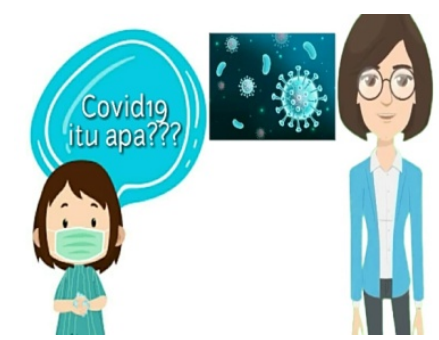

Gambar 1. Gambar Audio visual

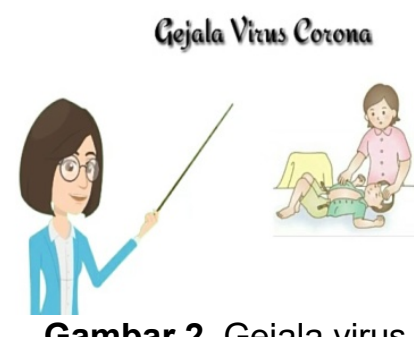

Gambar 2. Gejala virus 


\section{3) Perijinan penyuluhan secara offline dan} online.

Setelah video Valid maka pelaksana membuat surat perijinan pada beberapa subjek penyuluhan yaitu:

a. Penyuluhan 1 : Khusus Untuk Sekolah (pada kesempatan ini kami khususkan SD) yang ada di Bangka belitung. Pelaksana membuat surat keberapa sekolah yang terkondisikan secara offline maupun daring dengan baik.

b. Penyuluhan 2 : untuk Umum dan Mahasiswa dibuatkan brosur dan grup WA untuk memudahkan dalam pemberitahuan secara teknis

Pada Pelaksanaannya kegiatan ini dilakukan secara offline dan online melalui Zoom, serta berkolaborasi dengan narasumber dan pakar kesehatan. Sebagaimana diketahui Metode penyuluhan kesehatan ada berbagai macam jenis: Penyuluhan Perorangan, Metode penyuluhan Diskusi Kelompok. Dan Metode Penyuluhan Kesehatan Massa. Pelaksanaan pengabdian ini menggunakan penyuluhan kesehatan massa melibatakan partisipan dari berbagai kalangan dengan webiner menggunakan metode ceramah dan tanya jawab. Langkah-langkah yang digunakan dalam pelaksanaan kegiatan ini adalah sebagai berikut :

1. Peserta diberikan stimulasi melalui video yang berisi tentang kesehatan dimasa pendemi, stimulasi ini bertujuan untuk memberikan pengetahuan yang konkrit pada peserta sehingga mereka diharapkan lebih mudah menerima dan memahami materi yang disampaikan pada kegiatan ini baik untuk sekolah terdekat maupun yang online.

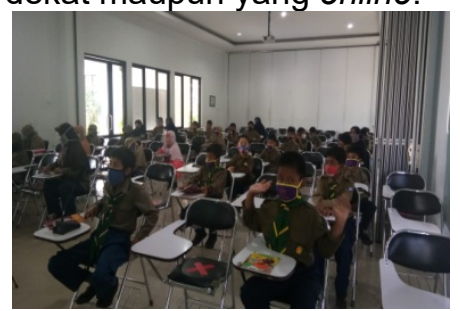

Gambar 3. Peserta offline

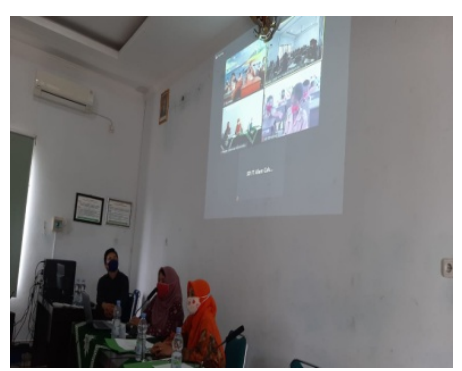

Gambar 4. Peserta online

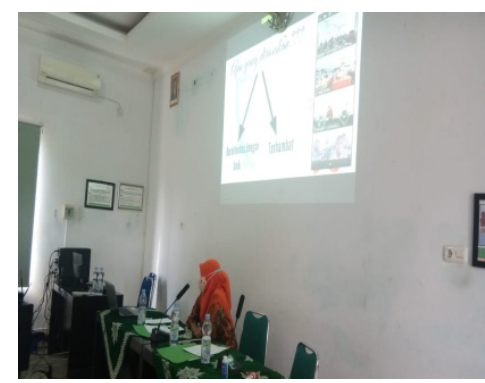

Gambar 5. Menampilkan Video Audio visual

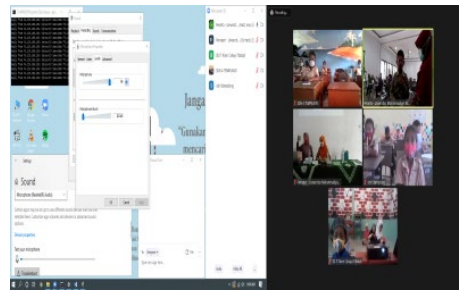

Gambar 6. Sama menyimak materi offline \& online via zoom

2. Melalui metode ceramah dan tanya jawab peserta diberikan materi oleh narasumber mengenai kesehatan dimasa pendemi dan new normal.

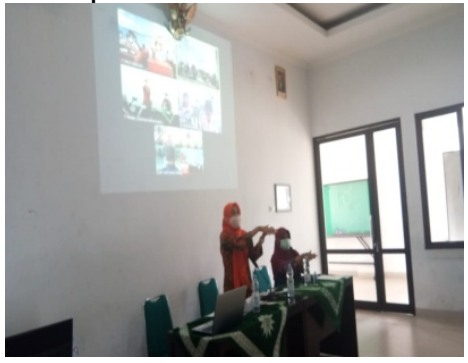

Gambar 7. Menjelaskan materi

3. Diakhir kegiatan pemateri memberikan kuis kepada peserta dan memberikan apresiasi berupa pemberian hadiah dan pembagian e-sertifikat.

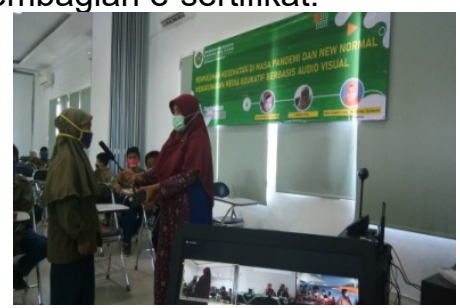

Gambar 8. Sesi pertanyaan

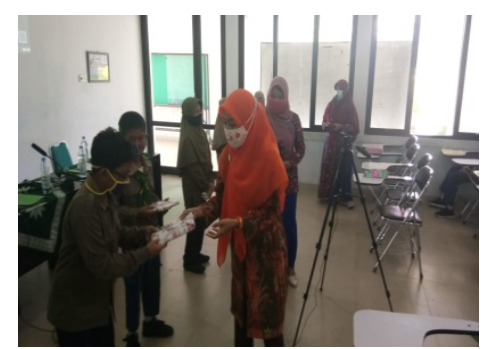

Gambar 9. Pemberian apresiasi berupa hadiah 


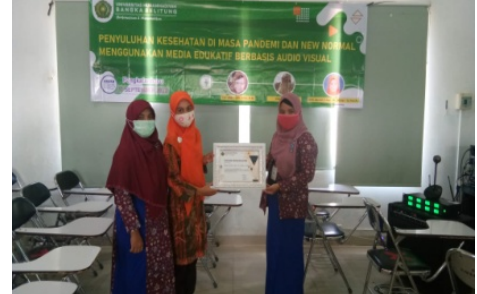

Gambar 10. Pemberian Sertifikat

4. Pelaksanaan penyuluhan secara online dilaksanakan secara bersamaan dengan yang offline dimana media edukatif berbasis audio visual bisa digunakan juga untuk masyrakat secara umum.

5. Di akhir pembagian E-sertifikat bagi peserta yang dengan video penyuluhan kesehatan yang berisi materi yang bermanfaat dan berisi rangkuman beberapa materi yang ada di media edukatif berbasis audio visual tersebut.

\section{SIMPULAN DAN SARAN}

Setelah dilaksanakannya penyuluhan kesehatan di masa pandemi dan new normal menggunakan media edukatif berbasis audio visual peserta sangat antusias ikut serta dengan ditampilkankannya media edukatif audio visual yang menarik dan langsung di jelaskan oleh pakar yang sesuai bidangnya.

Ini terlihat ketika anak-anak banyak yang bertanya setelah materi disampaikan. Dengan ini memberikan edukasi untuk menanamkan pehamanan yang kuat pada masa pandemi dalam menghadapi new normal. Perlunya pemberian edukasi melalui media berbasis audio visual bisa dirasakan bahwasanya covid-19 ini bukanlah sesuatu yang menakutkan sehingga menimbulkan rasa cemas yang berlebihan, tinggal bagaimana kita menyikapinya dengan baik dan mampu menjalankan sesuatunya berdasarkan protokol kesehatan.

\section{DAFTAR RUJUKAN}

Fujianto.,A. Jayadinata.,K.,A. Kurnia.,D. (2016) Penggunaan Audio visual Untuk Meningkatkan Hasil Belajar Siswa Pada Materi Hubungan Antar Makhluk Hidup, Jurnal Pena IImiah: Vol. 1, No, 1.

Haryani., Sahar., Sukihananto (2017) Penyuluhan Kesehatan Melalui Media Cetak Berpengaruh Terhadap Perawatan Hipertensi, Jurnal Keperawatan Indonesia, Volume 19 No.3.,hal 161-168 pissn 1410-4490, eissn 2354-9203 DOI 10.7454/jki.v19i3.469
Http://puspensos.kemsos.go.id/penyuluhanmelalui-media-sosial-tentangpentingnya-optimalisasi-sistemimunitas-tubuh-guna-memberantascovid-19-dan-dbd-di-indonesia Https://news.detik.com/berita/d5065539/bertambah-10-pasiensembuh-dari-corona-di-babel-capai-80persenhttps://news.detik.com/berita/d5065539/bertambah-10-pasiensembuh-dari-corona-di-babel-capai-80persen.

Muliyadi; M. Yasdar; Fitriani Sulaeman (2017). Penerapan Teknik Manajemen Diri Dapat Mengurangi Kebiasaan Prokrastinasi Akademik Mahasiswa STKIP Muhammadiyah Enrekang. Edumaspul - Jurnal Pendidikan,1(2), 92-103 